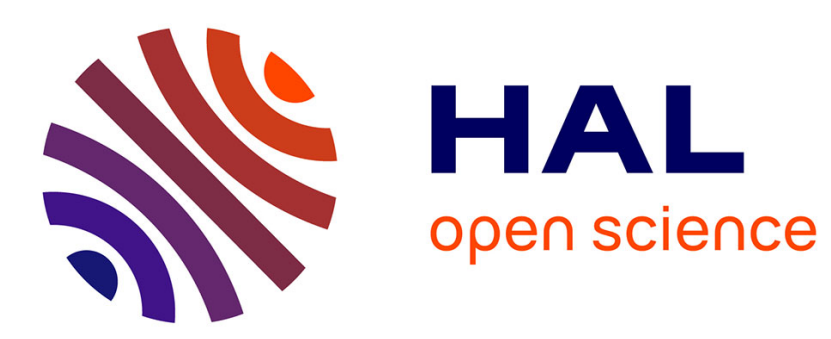

\title{
Unexpected enrichment of nitrogen during the diagenetic evolution of sedimentary organic matter
}

\author{
Jean-Paul Boudou, André A. Mariotti, J.L. Oudin
}

\section{To cite this version:}

Jean-Paul Boudou, André A. Mariotti, J.L. Oudin. Unexpected enrichment of nitrogen during the diagenetic evolution of sedimentary organic matter. Fuel, 1984, 63, pp.1508-1510. 10.1016/00162361(84)90215-1 . bioemco-00156950

\section{HAL Id: bioemco-00156950 \\ https://hal-bioemco.ccsd.cnrs.fr/bioemco-00156950}

Submitted on 24 Jun 2007

HAL is a multi-disciplinary open access archive for the deposit and dissemination of scientific research documents, whether they are published or not. The documents may come from teaching and research institutions in France or abroad, or from public or private research centers.
L'archive ouverte pluridisciplinaire HAL, est destinée au dépôt et à la diffusion de documents scientifiques de niveau recherche, publiés ou non, émanant des établissements d'enseignement et de recherche français ou étrangers, des laboratoires publics ou privés. 


\title{
Unexpected enrichment of nitrogen during the diagenetic evolution of sedimentary organic matter
}

\author{
Jean-Paul Boudouł., André Mariotti* and Jean-Louis Oudin † \\ Université d'Orléans, CNRS-ERA 601, 45046 Orléans, France \\ - Université Pierre et Marie Curie, Laboratoire de Géologie Dynamique, 4. Place de \\ Jussieu, 75230 Paris, France \\ +Compagnie Francaise des Pétroles, Direction Exploration, 218-228 Avenue du Haut- \\ Lévêque, 33605 Pessac Cedex, France
}

\begin{abstract}
This study examines the behaviour of nitrogen during coalification in two coal series: the sedimentologically homogeneous coal series of the Mahakam delta, Indonesia and a reference coal series composed of samples from several sources. The variations in the total nitrogen contents, in hydrolysable nitrogen, and in the natural isotopic abundance of ${ }^{15} \mathrm{~N}$ are reported. The behaviour of nitrogen during coalification presents three main stages: 1. a first stage where microbial and/or chemical degradations produce a loss of nitrogen: 2 . a second stage of preservation, where organic nitrogen does not take part in the reactions involved and consequently remains unchanged in the residual organic matter; and 3 . a third stage of thermal alteration, where nitrogen is mainly released with methane.
\end{abstract}

(Keywords: coal; coalification; nitrogen)

Compared with the data available on the character and distribution of carbon, hydrogen and oxygen in coals and kerogens, there is relatively little information on nitrogen, sulphur and phosphorus groups. At the beginning of coalification nitrogen occurs in humic like compounds ${ }^{t}$ and it might be thought that nitrogen groups, like oxygen groups, would disappear continuously during diagenesis. In fact, this Paper shows that nitrogen is preserved in sedimentary organic matter over a large part of the period of diagenesis.

A geochemical study of nitrogen in the sedimentologically homogeneous coal series of the Mahakam delta (Indonesia) is reported, and geochemical changes of nitrogen in this coal series are compared with those of another coal series. Data are related to the coal organic carbon, taken as a rank parameter which allows a comparison of the different evolution stages according to Stach et $a l^{2}$. The implications of variations in total nitrogen content for prediction of losses of organic matter and hydrocarbons during diagenesis are discussed.

The Mahakam delta is situated in Indonesia, on the eastern part of the Kutéi Basin, in south-eastern Borneo (Kalimantan). The geological setting and physical properties of Mahakam coals are extensively described elsewhere $^{3-8}$. This coal series is relatively uniform in terms of macerals as well as sedimentology: sedimentological conditions, climatic environment and the origin of the coal organic matter have always been constant during the delta history. Huminite or vitrinite represents $71-88 \%$ of these coals.

Mahakam samples, which range from lignite to bitu- minous coal, were provided by the Socièté TotalIndonésie and the Compagnie Française des Pétroles. They were obtained from cuttings taken at various depth intervals from many boreholes to a maximum depth of $3500 \mathrm{~m}$. As the number of samples was exceptionally high (600), sampling can be considered as representative over the coal series. Reference coals were provided by the Institut Français du Pétrole and by Dr H. W. Hageman and Dr M. Teichmüller. This reference set of samples does not represent all possible coal types (for instance, it contained no Gondwana coal samples).

Freeze-dried and crushed coals were analysed according to the methods of Durand and Monin ${ }^{9}$. Hydrolysis was performed in $6 \mathrm{~N} \mathrm{HCl}$ for $12 \mathrm{~h}$, under reflux. Hydrolysable nitrogen was analysed according to the Kjeldhal method ${ }^{10}{ }^{15} \mathrm{~N}$ was determined according to the method of Mariotti et al. ${ }^{11.12}$.

Figure $/$ shows the atomic $\mathrm{H} / \mathrm{C}$ tersus $\mathrm{O} / \mathrm{C}$ diagram ${ }^{13}$ for the Mahakam coal series, and it is compared with the atomic $\mathrm{H} / \mathrm{C}$ and $\mathrm{O} / \mathrm{C}$ ratios of the reference collection of vitrinite-rich coals from several origins. This diagram offers an insight into the course of the process occurring during coalification. It shows that the coalification processes of the two coal series (Mahakam and reference) did not differ significantly.

In Figure 2 it is seen that amounts of total nitrogen in Mahakam coals and in the reference coals increase significantly during the lignite and the subbituminous stages, then start to decrease during the bituminous stage. In the reference coals, the nitrogen values quickly decrease during the anthracite stage. Scatter due to initial type of plant matter ${ }^{2}$ is relatively low for the Mahakam coal series. The uniformity of the Mahakam coal series permits for the first time observation of an unexpected increase in 


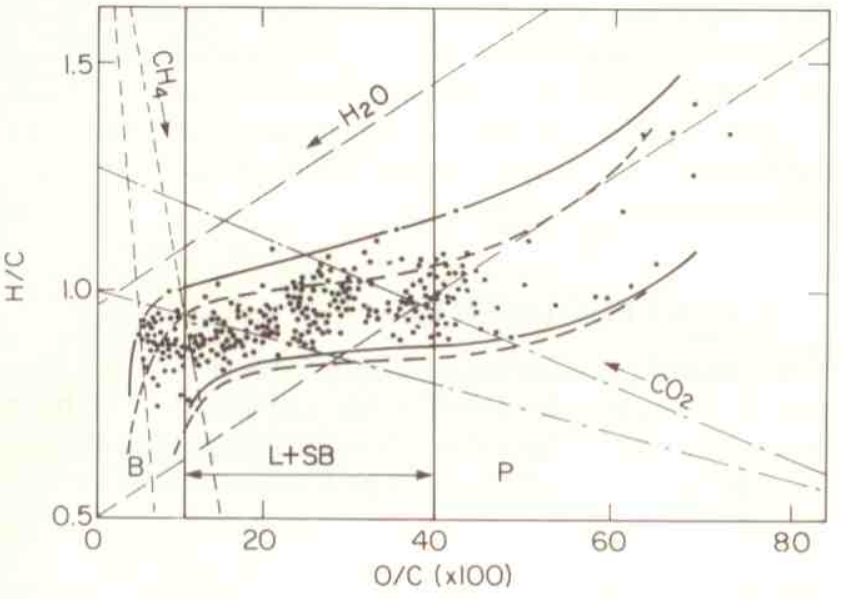

Figure 1 Atomic $\mathrm{H} / \mathrm{C}$ versus $\mathrm{O} / \mathrm{C}$ diagram. As in van Krevelen's diagram ${ }^{13}$, some lines have been drawn to denote the trends of simple reaction processes of dehydration (- - ) ;

decarboxylation (-.-.-); and demethanation (--.--). Samples of Mahakam coals (-) form an elongated cloud called development band. This development band $(-)$ and that of a reference coal series (- - - ) begin on the right with the peat stage $(P)$, then proceed to the lignite and subbituminous stages $(\mathrm{L}+\mathrm{SB})$ and the bituminous stage (B). These stages have been defined according to Stach et $a l^{2}$

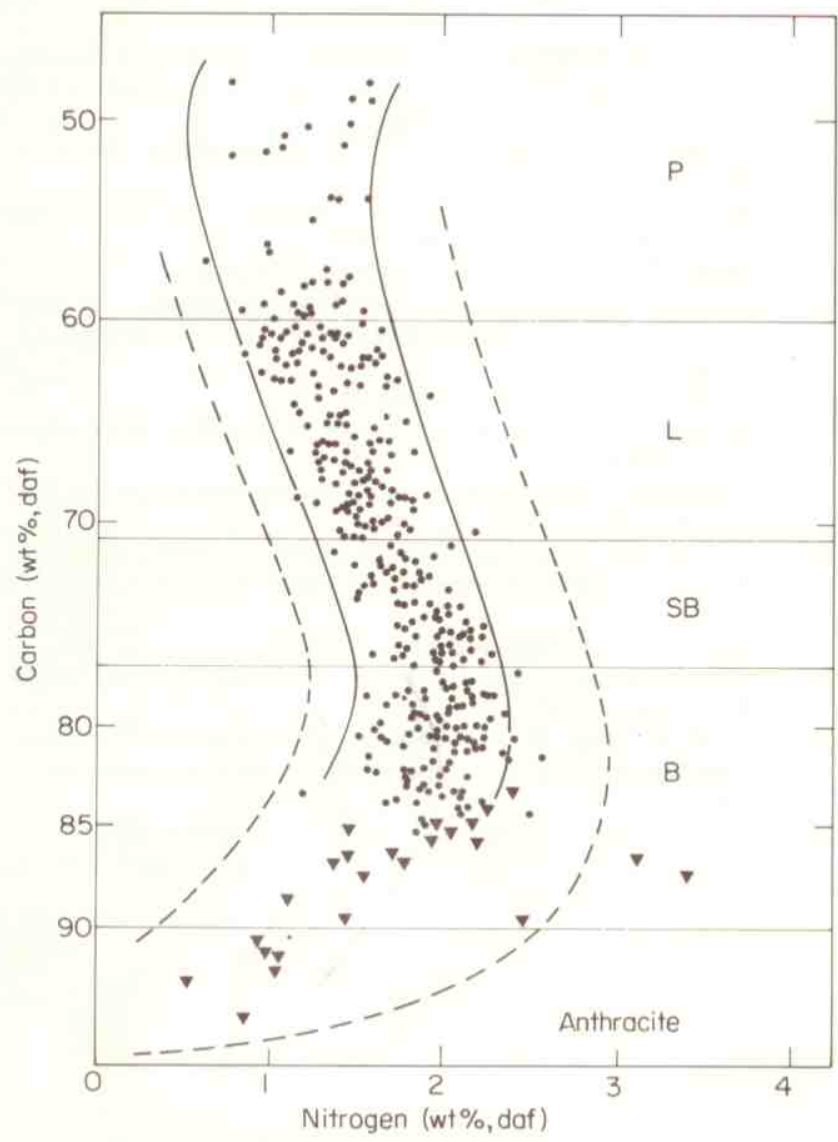

Figure 2 Nitrogen versus rank. Data are plotted as a function of coal organic carbon taken as rank parameter. Organic carbon enables us to set the P, L, SB, B and anthracite stages according to Stach et $a l^{2}{ }^{2}$ The envelope (- - of the Mahakam samples (2) is narrower than the envelope (...) of a reference coal series, which does not extend into the lowest ranks. Coals of high rank studied by Schapiro and Gray ${ }^{15}(\boldsymbol{\nabla})$ follow the same downward trend as the Mahakam coals, as predicted at the bituminous stage nitrogen percentages over the lignite and subbituminous stages, which up to now was less clear in other published work, because of the scatter within the data.

An explanation of this increase may simply be that the proportion of nitrogen increases because of the loss of more labile oxygen. This hypothesis is in accordance with the following observations. Hydrolysable nitrogen drops sharply at $51 \mathrm{wt} \% \mathrm{C}$ (daf), i.e. well down in the peat stage. At the beginning of the lignite stage, total nitrogen is no longer hydrolysable, as seen in Table 1 . Very unstable compounds would be completely decomposed and would furnish ammonia during early diagenesis. This decomposition could account for the early decrease in nitrogen percentages shown in Figure 2. The main part of the organic nitrogen is stable in lignites, and must be referred to as heterocyclic ${ }^{1}$.

Figure 3 shows a larger scattering of $\delta^{15} \mathrm{~N}$ values for lower rank Mahakam coals, compared with the higher ranks, where $\delta^{15} \mathrm{~N}$ values are not so dispersed. Given the homogeneity of the Mahakam coals, it may be that the shift in $\delta^{15} \mathrm{~N}$ observed during coal maturation are significant. If nitrogen loss, such as is expected during the peat and bituminous stages, is able to produce an isotopic fractionation, a partial proof of the preservation of the nitrogen of coal during the lignite and subbituminous stages may be inferred from the invariability of the $\delta^{15} \mathrm{~N}$ values during these stages.

Increase of nitrogen percentages is important for an understanding of organic matter diagenesis, as well as for establishing more clearly the mode of nitrogen evolution in coals of increasing rank. If it is assumed that nitrogen is accumulated in coal, the total loss of organic matter can be calculated and a quantitative model of evolution can be computed $^{14}$. If the nitrogen percentages at the beginning and end of a stage are $N 1$ and $N 2$, respectively, weight loss percentage is equal to $100(1-N 1 / N 2)$; this averages $24 \%$ during the lignite stage, and $7 \%$ during the subbituminous stage. Since $N 1$ and $N 2$ will not be known with a great degree of accuracy $( \pm 5 \%)$, the weight loss is not known very precisely, but at least an estimate can be made of the orders of magnitude and the amounts of products which are formed during diagenesis can be calculated.

Release of nitrogen occurs at the beginning of the bituminous stage, but is particularly noticeable at the anthracite stage, as shown for an anthracite series

Table 1 Hydrolysable nitrogen contents of representative samples of Mahakam coal series. Each representative sample is a mixture of several individual samples (fresh vegetal samples, litter samples, buried samples having a same huminite-vitrinite reflectance)

Total organic carbon Hydrolysable nitrogen

in coal (wt \%, daf)

(mg/100 mg nitrogen) 


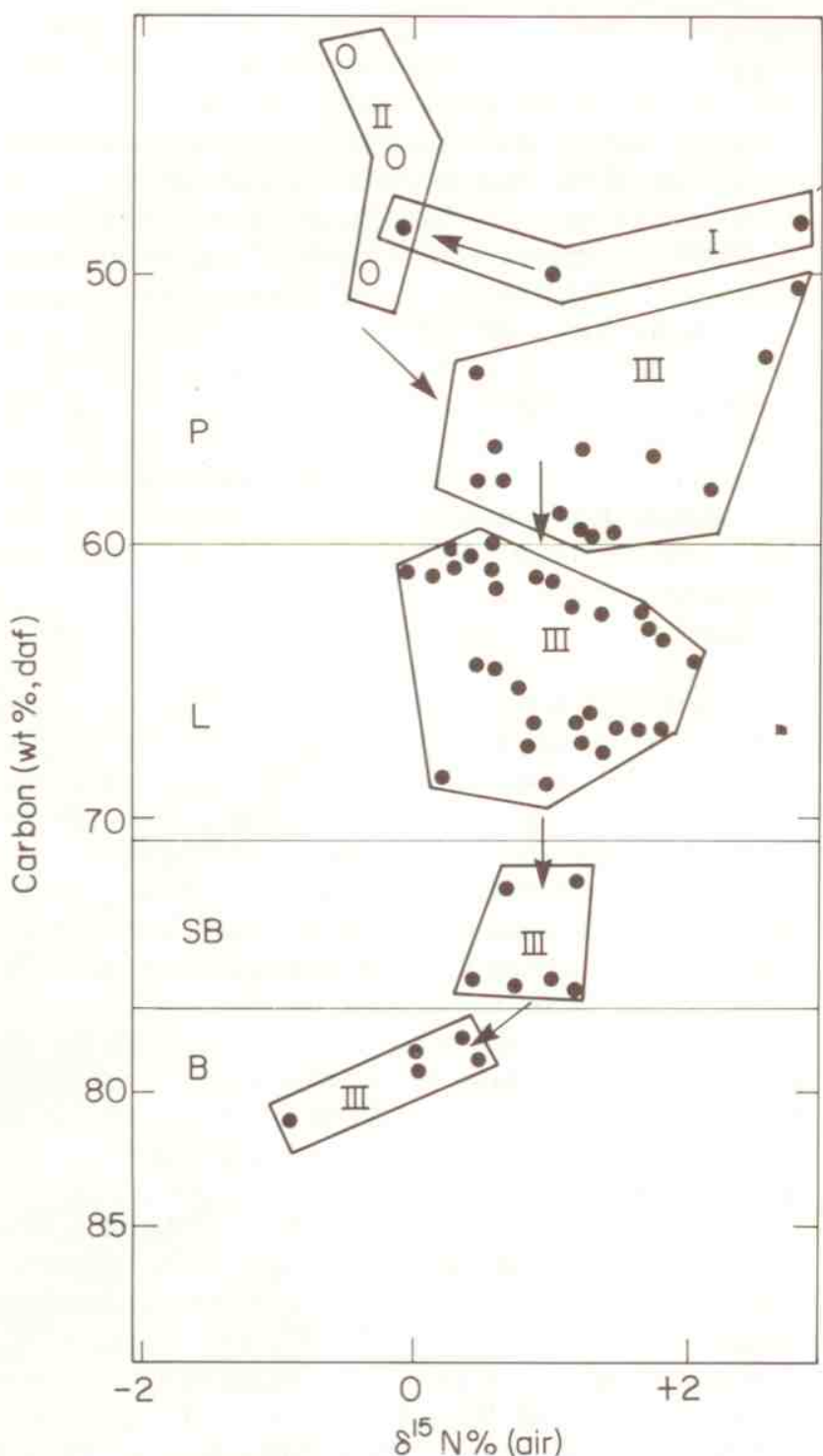

Figure $3 \quad \delta^{15} \mathrm{~N}$ for Mahakam coals. Data are plotted versus organic carbon percentages, as in Figure 2. (I) refers to the area of fresh vegetation (Nypa fruticans, a characteristic species of the deltaic vegetation), (II) refers to the area of litter (detritus of various plants from the surface deposit), (III) refers to areas of buried samples (cuttings obtained at various depth intervals)

(Figure 2$)^{15}$. The mechanism involved in the process of thermal nitrogen elimination could also be responsible for gas formation ${ }^{16}$, which begins later in the geothermal sequence than does oil formation. This would explain the presence of nitrogen in some gas inclusions of metamorphized rocks ${ }^{21}$, and in some gas accumulations ${ }^{17-20}$.
This research has been commenced because petroleum geologists are just beginning to drill into the major deposits of gas below the level at which oil forms. Further studies are now in progress to establish the mechanism of nitrogen loss and its connection with gas accumulation.

\section{ACKNOWLEDGEMENTS}

The authors acknowledge Total-Indonésie and Compagnie Française des Pétroles for permission to publish these data. The authors thank Institut Français du Pétrole for funding which allowed the performance of this work.

\section{REFERENCES}

1 Flaig, W. Chem. Geol. 1968, 3, 161

2 Stach, E., Mackowsky, M. Th., Teichmuller, M., Taylor, G. H., Chandra, D. and Teichmuller R. 'Coal Petrology', Gebrüder Borntraeger, Berlin-Stuttgart, 1975

3 Magnier, Ph., Oki, T. and Kartaadiputra, L. in "9th World Petr. Congr.' 1975, 2, 239

4 Allen, G. P., Laurier, D. and Thouvenin, J. 'Etude sédimentologique du delta de la Mahakam', Compagnie Française des Pétroles, 1979

5 Verdier, A. C., Oki, T. and Svardy, A. 'Am. Assoc. Pet. Geol. Convention, Houston', 1979

6 Combaz, A. and Dematharel, M. Bull. Am. Assoc. Pet. Geol. 1978, 62, 1684

7 Durand, B. and Oudin, J. L. in '10th World Petr. Congr.' 1979, 1 , 3

8 Boudou, J. P. 'Diagenèse organique de sédiments deltaiques (delta de la Mahakam, Indonésie)' PhD Thesis, University of Orléans, France, 1981

9 Durand, B. and Monin, J. P. in 'Kerogen' (Ed. B. Durand), Technip, Paris, 1980 , p. 113

10 Bremmer, J. M. 'Methods of soil analysis', Am. Soc. Agron. Publish, Madison, Wisconsin, 1965

11 Mariotti, A. and Letolle, R. Analusis 1978, 6, 421

12 Mariotti, A. 'Apports de la géochimie isotopique à la connaissance du cycle de l'azote', $P h D$. Thesis, University of Paris VI, France, 1982

13 van Krevelen, D. W. Fuel 1950, 29, 269

14 Boudou, J. P., Pelet, R. and Letolle, R. Geochim. Cosmochim. Acta. 1984 48, 1357-1362

15 Schapiro, N. and Gray, R. J. Am. Chem. Soc. Adv. Chem. Ser. (Ed. R. F. Gould) $1966, \mathbf{5 5}, 196$

$16 \mathrm{Klein}, \mathrm{J}$. and Juntgen, H. in Adv. in Organic Geochemistry (Ed. H. R. Gaertner and H. Wehner), Pergamon Press, New York, 1972, p. 647

17 Patjin, R. J. H. Erdöl und Kohle 1964, 17, 2

18 Lutz, M., Kaasschiieter, J. P. H. and van Wijhe, D. H. '9th World Petr. Congr.' 1975, 2, 1

19 Stahl, N., Boigk, H. and Wollanke, G. in 'Advances in Organic Geochemistry' (Ed. R. Campos and R. Goni), Enadimsa, 1966, p. 539

20 Tissot, B. and Bessereau, G. Rev. Inst. Fr. Pétrole 1982, 37, 63

21 Guilhaumou, N., Dhamelincourt, P., Touray, J. C. and Touret, J. Geochim. Cosmochim. Acta 1981, 45, 657 